\title{
Pengaruh Jalan Sehat terhadap Kualitas Hidup Penderita Diabetes Mellitus Tipe 2 di Puskesmas
}

\author{
The Effect of Healthy Walk to Quality of Life Diabetes Mellitus \\ Type 2 in Public Health Center
}

\author{
Ihsan Taufiq ${ }^{1, \bigotimes}$
}

${ }^{1}$ Jurusan Keperawatan, Politeknik Kesehatan Tanjung Karang, Indonesia

${ }^{凶}$ Corresponding author: ihsantaufiq1112@gmail.com

\section{Kata kunci: \\ Kualitas hidup, Aktivitas fisik, Jalan sehat, DM tipe 2.}

Keyword:

Quality of life, Physical activit, Healthy walk, DM type 2.

\begin{abstract}
Abstrak
Latar Belakang: Penyakit Diabetes Mellitus (DM) menyebabkan penurunan kualitas hidup disemua domain. Penyebab yang paling sering diabaikan penderita DM adalah tidak melaksanakan aktivitas fisik secara teratur. Tujuan: Tujuan penelitian ini untuk mengetahui pengaruh jalan sehat terhadap kualitas hidup penderita DM tipe 2 di Puskesmas wilayah Kotabumi Lampung Utara Tahun 2017. Metode: Penelitian ini menggunakan kuasi eksperimen pre post test design dengan kelompok kontrol. Jumlah sampel terdiri atas kelompok perlakuan dan kelompok kontrol masing-masing kelompok 22 responden. Kelompok perlakuan adalah responden yang dilakukan intervensi jalan sehat, kemudian dilakukan pengukuran kualitas hidup penderita DM tipe 2, sedangkan kelompok kontrol tidak melakukan kegiatan jalan sehat. Analisis data menggunakan $t$ test dependent. Hasil: Hasil penelitian menunjukkan terdapat pengaruh jalan sehat terhadap kualitas hidup penderita DM tipe 2 di Puskesmas wilayah Kotabumi Lampung Utara ( $\mathrm{p}=0,007)$. Simpulan: Jalan sehat meningkatkan kualitas hidup penderita DM tipe 2 meliputi aspek kesehatan fisik, kesehatan psikologis, hubungan sosial dan lingkungan.
\end{abstract}

\begin{abstract}
Background: Diabetes Mellitus (DM) causes a decrease in quality of life in all domains. The most often overlooked cause of DM patients is not carrying out physical activity regularly. Purpose: The purpose of this study was to determine the effect of healthy pathways on the quality of life of type 2 DM patients in the Health Center in Kotabumi North Lampung in 2017. Methods: This study used quasi-experimental pre-post test design with a control group. The number of samples consisted of treatment groups and control groups, each group of 22 respondents. The treatment group was the respondents who carried out healthy walks of intervention, then measured the quality of life of patients with type 2 diabetes mellitus, while the control group did not carry out healthy walking activities. Data analysis uses $t$ test dependent. Results: The results showed that there was an effect of healthy pathways on the quality of life of patients with type 2 diabetes mellitus in the health centers in Kotabumi, North Lampung ( $p=0.007)$. Conclusions: Healthy paths improve the quality of life for patients with type 2 diabetes, including aspects of physical health, psychological health, social and environmental relations.
\end{abstract}




\section{Pendahuluan}

Kualitas hidup pasien Diabetets Mellitus (DM) mengalami penurunan (Spasi, Veli, Cati, Stefanovi, \& Cvetkovi, 2014). Kualitas hidup sebagai persepsi individu dari posisi mereka dalam kehidupan dalam konteks budaya dan sistem nilai di mana mereka tinggal dan dalam hubungannya dengan tujuan mereka, harapan, standar dan kekhawatiran (WHO, 2004).

Penderita diabetes mellitus dapat mengalami masalah komplikasi serius dalam jangka panjang. Beberapa masalah yang muncul, seperti gangguan mata, ginjal, pembuluh darah dan saraf, yang menyebabkan kebutaan, penyakit ginjal parah, amputasi, penyakit serebrovaskular (CVA) dan myocardial infarction (MI). Komplikasi tersebut dapat terjadi jika tidak dilakukan tindakan pencegahan, pengendalian, dan pengobatan penyakit dengan tepat dan cepat mengenai (Mahdavi, Etemad, Haider, \& Alavinia, 2013).

Penyakit Diabetes mellitus memiliki komplikasi kronik yang sangat banyak diantaranya ada terjadinya makro dan mikroangiopati. Beberapa masalah jangka panjang yang terjadi adalah gangguaan pada ginjal berupa nefropati, gangguan pada sistem saraf berupa stroke gangguan pada jantung berupa miokard infark dan juga permasalahan akibat makroangipati adalah terjadi ulkus kaki diabetik yang berdampak terjadinya amputasi. Masalah-masalah tersebut akan terjadi jika tidak dilakukan penanganan berupa pencegahan, kontrol dan tindakan langsung yang tepat (Waspadji, 2009).

Penderita diabetes memiliki risiko 15 kali lebih besar mengalami amputasi dibandingkan orang sehat. Temuan dari beberapa studi berbasis pada populasi yang berbeda, prevalensi retinopati diabetes menunjukkan bahwa nilai prevalensi lebih besar 3\% sampai 10\% di antara pasien diabetes. Prevalensi kebutaan pada penderita diabetes telah dilaporkan dalam studi yang berbeda dan rentang 0,4-1\%. Kontrol diabetes dan komplikasi menunjukkan bahwa manajemen umum kadar glukosa darah adalah penting dalam mengurangi perkembangan retinopati diabetes. Beberapa penelitian telah menunjukkan bahwa tingkat nefropati dapat dikurangi dengan kontrol jangka panjang melalui tes laboratorium tahunan dan pengobatan yang tepat pada mikroalbuminuria (Umpierre et al., 2011).

Latihan fisik terstruktur yang terdiri dari latihan aerobik, latihan ketahanan ataupun keduanya berhubungan dengan penurunan $\mathrm{HbA}_{1 c}$ pasien DM tipe II. Latihan fisik terstruktur lebih dari 150 menit perminggu menurunkan nilai $\mathrm{HbA}_{1 \mathrm{c}}$ lebih besar dibandingan dengan apabila kurang dari 150 menit perminggu (Umpierre et al., 2011). Latihan fisik adalah pilar penting dalam manajemen diabetes, bersama dengan intervensi diet dan farmakologis. Pedoman saat ini menyarankan bahwa pasien dengan diabetes tipe II harus melakukan setidaknya 150 menit per minggu dengan intensitas sedang latihan aerobik dan harus melakukan latihan resistance 3 kali per minggu. Manfaat latihan jasmani bagi penderita diabetes antara lain meningkatkan penurunan kadar glukosa darah, mencegah kegemukan, ikut berperan dalam mengatasi kemungkinan terjadinya komplikasi aterogenik, gangguan lemak darah, menormalkan tekanan darah, serta meningkatkan kemampuan kerja (Umpierre et al., 2011).

Fisik yang tidak aktif diidentifikasi menjadi penyebab keempat dari global mortality ( $6 \%$ kematian global). Selanjutnya diikuti dengan tekanan darah tinggi (13\%), penggunaan tembakau (9\%) dan gula darah tinggi (6\%). Overweight dan obesitas 5\% dari global mortality (WHO, 2010). Angka kejadian fisik yang tidak aktif terus meningkat di beberapa negara dengan implikasi utamanya terhadap kesehatan umum seseorang secara luas dan untuk prevalence Non Communicable Disease (NCDs) atau penyakit tidak menular, seperti penyakit cardiovascular, peningkatan glukosa darah dan overweight. Fisik yang tidak aktif diestimasikan $21-25 \%$ sebagai penyebab prinsip dari penyakit kanker payudara dan kolon, $27 \%$ diabetes mellitus dan $30 \%$ penyakit jantung iskemia. Sebagai tambahan, kejadian NCDs saat ini mendekati separuh penyakit secara global. Hal ini diestimasikan dari setiap 10 kematian, 6 diantaranya berkontribusi kondisi NCDs (WHO, 2010).

Latihan fisik berjalan berpengaruh signifikan terhadap pengontrolan kadar gula darah bagi penderita DM tipe II dilihat dari nilai $\mathrm{HbA1c}$ yang menurun dari sebelum latihan dan sesudahnya. 
Namun demikian, belum pernah dilakukan evaluasi kualitas hidup penderita Diabetes Mellitus tipe 2 . Penderita DM yang didiagnosis, setidaknya setengah masih belum mencapai kontrol glikemik yang memuaskan, meskipun sudah ada perawatan yang efektif. Sebagai konsekuensi, jutaan orang dengan diabetes mengalami peningkatan komplikasi serius dari penyakit ini. Risiko komplikasi dikaitkan dengan genetika, dan durasi hiperglikemia. Komplikasi kronis penyakit bertanggung jawab atas morbiditas dan mortalitas yang tinggi dan secara signifikan mengurangi kualitas hidup pasien (Spasi et al., 2014).

Informasi dari Pengelola penderita DM di Puskesmas Kotabumi II, penyakit DM menempati urutan ketiga dari sepuluh penyakit terbesar, setelah nasopharingitis akut (common cold) dan hipertensi. Adapun penderita DM yang dikelola berjumlah 111 orang. Puskesmas Kotabumi II, Puskesmas Madukoro, dan Puskesmas Abung Kunang sudah melaksanakan kegiatan-kegiatan pengelolaan penderita DM, yaitu kegiatan senam DM, penyuluhan, pemeriksaan fisik, pemeriksaan gula darah, home care dan lain-lain. Hasil studi pendahuluan para penderita DM melaksanakan latihan fisik berupa senam DM seminggu satu kali.

Komplikasi jangka panjang yang timbul pada penderita DM tipe II bila tidak dikelola dengan baik adalah terjadinya makroangiopati dan mikroangiopati. Masalah kesehatan yang muncul, seperti gangguan mata, ginjal, pembuluh darah dan saraf, yang menyebabkan kebutaan, penyakit ginjal parah, amputasi, penyakit serebrovaskular (CVA) dan Myocardial Infarction (MI). Komplikasi kronis penyakit bertanggung jawab atas morbiditas dan mortalitas yang tinggi dan secara signifikan mengurangi kualitas hidup pasien DM.

Aktivitas fisik yang tepat sudah menjadi rekomendasi WHO dalam mencegah timbulnya penyakit-penyakit kronik diantaranya penyakit DM. Penderita DM tipe 2 di Puskesmas wilayah Kotabumi sudah dilakukan pengelolaan latihan fisik, sampai saat ini belum diukur kualitas hidupnya. Penelitian bertujuan untuk mengetahui pengaruh jalan sehat terhadap kualitas hidup penderita Diabetes Mellitus Tipe II di Puskesmas wilayah Kotabumi Lampung Utara Tahun 2017.

\section{Metode}

Rancangan penelitian ini menggunakan kuasi eksperimen pre post tes design dengan kelompok control. Kelompok perlakuan dilakukan intervensi jalan sehat seminggu 3 kali, kemudian dilakukan pengukuran kualitas hidup penderita DM tipe 2, sedangkan kelompok kontrol melakukan aktifitas sehari-hari berupa senam DM yang dilaksanakan seminggu sekali, tanpa jalan sehat yang terprogram. Penelitian dilaksanakan di Puskesmas wilayah Kotabumi terdiri dari Puskesmas Kotabumi II, Puskesmas Madukoro dan Puskesmas Abung Kunang Kabupaten Lampung Utara pada bulan Oktober - November 2017.

Populasi pada penelitian ini adalah penderita DM tipe 2 yang tercatat dalam buku registrasi di Puskesmas Kotabumi II, Puskesmas Abung Kunang dan Puskesmas Madukoro. Besar sampel pada penelitian ini menggunaan rumus besar sampel untuk uji hipotesis terhadap dua proporsi dua kelompok berpasangan (Sastroasmoro, 2010).

$$
\mathrm{n}_{1}=\mathrm{n}_{2}=\left(\begin{array}{c}
{[\mathrm{Z} \alpha+\mathrm{Z} \beta] \mathrm{S}} \\
---------
\end{array}\right]^{2}
$$

Sampel dihitung dengan $Z \alpha=1,96 Z \beta=1.28 \mathrm{~S}=0,68 \mathrm{X}_{1}=8,44 \mathrm{X}_{2}=7,38$ (Aprina, Eka, 2015), diperoleh masing-masing untuk kelompok perlakuan dan kelompok kontrol berjumlah 22 responden. Kriteria inklusi responden adalah penderita DM tipe 2, mengkonsumsi obat hipoglikemia oral (OHO) dan menandatangani informed consent. Adapun kriteria eksklusi responden adalah penderita DM mengalami komplikasi, seperti gangguan jantung, gangguan ginjal, gangguan hati, mengalami anemia 
berat serta mengalami diabetic foot ulcer (DFU). Pemilihan sampel pada penelitian ini dengan menggunakan non probabilty sampling, yaitu consecutive sampling atau pengambilan sampel dimana seluruh sampel yang ada dan memenuhi kriteria inklusi diambil sampai memenuhi besar sampel yang telah ditentukan (Sastroasmoro, 2010).

Pengumpulan data dengan melakukan wawancara menggunakan alat ukur kuesioner World Health Organization Quality Of Life (WHOQOL). Instrumen kuesioner WHOQOL adalah alat ukur yang disusun oleh WHO yang dapat digunakan dengan berbagai latar belakang budaya (WHO, 2004) merupakan alat ukur yang valid dan reliabel (Salim, Sudharma, Kusumaratna, \& Hidayat, 2007), sedangkan, untuk memastikan bahwa responden melaksanakan intervensi dengan benar menggunakan lembar observasi dan standar operasional prosedur (SOP).

Perlakukan yang diberikan pada kelompok intervensi pada penelitian ini adalah: (1) Melakukan informed consent; (2) Melakukan penapisan responden sesuai kriteria eksklusi dengan mastikan kembali bahwa responden tidak ada kontraindikasi melakukan latihan ini; (3) Respoden melakukan jalan sehat dengan waktu latihan dilaksanakan pada pagi hari (pukul 06.00 - $07.00 \mathrm{WIB}$ ), lokasi latihan berjalan berdekatan dengan Puskesmas, rute jalan yang digunakan ada bagian yang landai dan ada sedikit jalanan yang menanjak dan menurun. Latihan berjalan dilaksanakan di pelataran/ lingkungan Islamic center dengan jarak tempuh kurang lebih 3,5 km, responden menggunakan alas kaki saat program latihan, responden diajarkan cara menghitung denyut nadi, menjelaskan program latihan berjalan ini dengan tahapan yaitu berdoa, pemanasan 5 menit, berjalan 50 menit, pendinginan 5 menit, (4) Responden melakukan program latihan ini secara teratur tiga kali dalam seminggu pada hari senin, rabu dan jumat masing-masing selama 50 menit, sehingga total program latihan berjalan ini adalah 150 menit dalam seminggu dan dilakukan selama 4 minggu dengan didampingi oleh peneliti dan asisten peneliti (enumerator), sehari sebelum latihan, peneliti mengingatkan responden dengan SMS, (5) Dilakukan pengukuran kualitas hidup penderita DM tipe 2 (responden) menggunakan kuesioner WHOQOL untuk kelompok perlakuan maupun kelompok kontrol. Analisis data hasil pengukuran menggunakan analisis univariat dan bivariat. Analisis bivariat menggunakan $t$ test dependent dengan tingkat kepercayaan $95 \%$ dan tingkat kemaknaan $(\alpha)=0,05$.

\section{Hasil}

\section{Karakteristik responden}

Karakteristik responden penelitian menggambarkan usia, jenis kelamin, tingkat pendidikan, tingkat pendapatan, lama sakit DM, dan skor kualitas hidup. Hampir seluruh responden adalah perempuan sebesar $79,5 \%$. Sebagian besar responden dengan tingkat pendidikan sekolah dasar (SD) sebesar $43,18 \%$.

Rerata umur adalah 59,20 tahun $(\mathrm{SD}=8,67)$ dengan usia termuda adalah 40 tahun dan usia tertua 78 tahun. Rerata pendapatan perbulan adalah $\mathrm{Rp} 2.230 .000$ ( $\mathrm{SD}=1.220 .215,99)$ dengan pendapatan terendah adalah Rp 200.000 dan pendapatan tertinggi adalah. Rp 5.000.000. Rerata lama sakit DM adalah 6,45 tahun ( $\mathrm{SD}=4,34$ tahun) dengan lama sakit $\mathrm{DM}$ terendah adalah 1 tahun dan sakit DM terlama adalah 17 tahun.

\section{Skor kualitas hidup}

Skor kualitas hidup pada tabel 1 diukur dengan beberapa dimensi yang luas yaitu: kesehatan fisik, kesehatan psikologis, hubungan social dan lingkungan. Aspek mengenai kualitas hidup (WHO, 1996). Hasil penelitian menunjukkan rerata skor kualitas hidup awal (sebelum perlakuan) adalah 78,77 $(\mathrm{SD}=11,53$; skor minimum 51 - skor maksimum 97). Sedangkan, rerata skor kualitas hidup akhir (sesudah perlakuan) adalah 80,73 ( $\mathrm{SD}=0,469$; skor minimum 59 - skor maksimum 97). 


\section{Analisis variabel perancu responden terhadap skor kualitas hidup}

Analisis variabel perancu untuk mengetahui hubungan murni antara variabel bebas dan variabel terikat. Variabel perancu merupakan karakteristik dari responden. Hasil analisis pearson correlation

Tabel 1.

Skor kualitas hidup penderita DM Tipe 2 di Puskesmas

\begin{tabular}{cccc}
\hline Variabel & Mean & SD & Minimimal - Maksimal \\
\hline Skor kualitas hidup 1 & 78,77 & 11,53 & $51-97$ \\
Skor kualitas hidup 2 & 80,73 & 9,46 & $59-97$ \\
\hline
\end{tabular}

pada tabel 2 menunjukkan tidak ada hubungan jenis kelamin dengan kualitas hidup penderita DM tipe 2 ( $\mathrm{p}=0,938)$, tidak ada hubungan tingkat pendidikan dengan kualitas hidup penderita DM tipe 2 ( $\mathrm{p}=0,082)$, tidak ada hubungan usia dengan kualitas hidup penderita DM tipe $2(\mathrm{p}=0,884)$, ada hubungan status social ekonomi dengan kualitas hidup penderita DM tipe $2(\mathrm{p}=0,039)$, tidak ada hubungan lama sakit DM dengan kualitas hidup penderita DM tipe 2 ( $\mathrm{p}=0,232)$.

Tabel 2.

Analisis Variable Perancu terhadap Skor Kualitas Hidup Penderita DM Tipe 2 di Puskesmas

\begin{tabular}{lc}
\hline \multicolumn{1}{c}{ Variabel Perancu } & P value \\
\hline Jenis Kelamin & 0,938 \\
Pendidikan & 0,082 \\
Usia & 0,884 \\
Status Sosial Ekonomi & 0,039 \\
Lama Sakit DM & 0,232 \\
\hline
\end{tabular}

\section{Analisis bivariat}

Analisis bivariat untuk mengetahui ada atau tidak adanya perbedaan skor kualitas hidup antara kedua kelompok. Tabel 3 menunjukkan terdapat perbedaan skor kualitas hidup antara kelompok intervensi (jalan sehat) dengan kelompok kontrol (tanpa jalan sehat) $(p=0,007 ; \alpha=0,05)$ atau terdapat pengaruh jalan sehat terhadap kualitas hidup penderita DM tipe 2.

Tabel 3.

Analisis Pengaruh Jalan Sehat terhadap Kualitas Hidup Penderita DM Tipe 2 di Puskesmas

\begin{tabular}{lccccccc}
\hline \multicolumn{1}{c}{ Perlakuan } & Mean & SD & Beda Rerata 95\% CI & T & Df & n & P value \\
\hline Jalan sehat & 80,73 & 8,65 & $2,11: 12,79$ & 2,81 & \multirow{2}{*}{42} & \multirow{2}{*}{44} & \multirow{2}{*}{0,007} \\
Tanpa jalan sehat & 73,27 & 8,90 & & & & & \\
\hline
\end{tabular}

\section{Pembahasan}

\section{Latihan berjalan}

Penelitian ini menunjukkan terdapat pengaruh jalan sehat terhadap kualitas hidup penderita DM tipe $2(\mathrm{p}=0,007 ; \alpha=0,05)$. Hasil analisis diperoleh perbedaan rata-rata skor kualitas hidup pada kelompok intervensi 80,73 lebih baik dibandingkan kelompok kontrol 73,27.

Kualitas hidup pasien DM yang memiliki komplikasi berupa ulkus (foot ulcer) akan turun dan semakin menurun setelah dilakukan mayor amputasi (Gershater et al., 2009). Aktivitas jalan sehat dapat memperbaiki nilai ABI pasien sebagaimana penelitian yang yang berjudul "correlation between ankle brachial index before and after shuttle walk test (SWT)" menghasilkan ada penurunan rerata ABI saat istirahat (rest) dengan ABI setelah latihan (effort).

Penelitian ini dilakukan pada respon-den dengan peripheral obstruktif arterial disease (PAOD), nilai $\mathrm{ABI}$ istirahat $>0.3$ dan $<0.9$ dan tanpa kontra indikasi: $\mathrm{CHF}$, angina tidak stabil, arritmia. Latihan 
dilakukan di lahan terbuka dengan jarak 10 meter yang diberi batas dengan penanda 2 (dua) cone. Dilakukan semakin lama semakin cepat (setiap satu menit semakin dipercepat) sampai pasien lelah, timbul gejala claudikasi (nyeri saat latihan). Diperoleh tidak ada korelasi antara nilai ABI pre dan post walking dan variable yang mempengaruhi SWT (distance, time, speed / jarak, waktu dan kecepatan). Rerata ABI- $\mathrm{r}$ (rest) $0.66 \pm 0.14$ (95\%CI 0.38-0.94); dan rerata ABI-e (effort) $0.42 \pm 0.19$ (95\%CI 0.24$0.61)$. Terdapat penurunan rerata ABI $0.24 \pm 0.14$ setelah latihan dan istirahat $(\mathrm{p}<0.0005)$ (Teixeira da Cunha-Filho et al., 2007). Selain itu, penelitian tentang pengaruh jalan sehat terhadap nilai ABI pada penderita DM tipe 2 menunjukkan bahwa ada perbedaan yang signifikan antara pengukuran awal dan akhir setelah melakukan aktivitas jalan sehat selama 1 (satu) bulan secara rutin $\mathrm{p}=0.033$ (Taufiq, Ihsan, 2017). Penelitian yang berjudul the quality of life in patient diabetes mellitus type 2 menunjukkan bahwa diabetes mellitus tipe 2 mempengaruhi efek negative terhadap kualitas hidup (Brown, Brown, Sharma, Brown, \& Gozum, 2000). Hal ini diakibatkan karena adanya komorbiditas. Komorbiditas dihubungakan dengan tingginya nilai HbA1c. Tidak ada perbedaan pengkajian kualitas hidup terhadap jenis kelamin, umur atau tipe terapi yang digunakan(Bosic Zivanovic D., Medic-Stajanoska M., 2012). Penelitian lain menunjukkan bahwa jalan sehat menu-runkan nilai HbAlc, ada perbedaan yang signifikan rata-rata skor nilai $\mathrm{HbA1c}$ antara pengukuran sebelum $(8,44)$ dan sesudah dilakukan intervensi berjalan (7,33). ( $\mathrm{p}=0,002 ; \alpha=0,05)$ (Aprina, Eka, 2015).

Latihan yang diikuti dengan intervensi diet merupakan terapi garis pertama pada pasien DM. Menurutnya latihan dapat mengontrol kadar gula darah sehingga mampu untuk mencegah terjadinya penyakit lain yang diakibatkan oleh peningkatan gula darah seperti penyakit kardiovaskuler (Gulve, 2008) (Waspadji, 2009). Pentingnya Diabeti melakukan latihan utuk menjaga kualitas hidup sehat.

\section{Pengaruh latihan berjalan terhadap kualitas hidup}

Penyakit arteri perifer pada ektrimitas bagian bawah sering terjadi tanpa gejala maupun dengan gejala pada usia lebih dari 50 tahun (Crawford et al., 2016). Pada penelitian ini responden tidak mengalami iskemia kritis pada kakinya (tanpa leg ulcer/gangrene). Gangguan pada kaki diabetes dapat diketahui dari nilai Ankle brachial Index (ABI). ABI adalah rasio tekanan sistolik yang diukur pada ankle dan tekanan sistolik yang diukur pada lengan. ABI adalah indikator adanya atherosclerosis pada pembuluh darah dan dapat dijadikan sebagai penanda adanya gangguan kardiovaskuler dan gangguan fungsi walau tidak ada tanda/ gejala penyakit pembuluh darah perifer. Peningkatan ABI dapat dipengaruhi oleh usia karena terjadinya kekakuan arteri (Aboyans et al., 2012).

Latihan kaki yang dilakukan mengakibatkan terjadinya peningkatan tekanan sistol pada sirkulasi sentral yang diukur pada lengan. Pada ektrimitas yang tidak dilakukan latihan akan mengalami vasokontriksi perifer. Pada saat dilakukan latihan akan terjadi vasodilatasi pembuluh darah. Kondisi ini akan mengakibatkan terjadinya penurunan nilai ABI. Pemulihan ABI juga dipengaruhi oleh durasi latihan. Seseorang yang melakukan latihan berjalan terjadi gerakan berulang-ulang secara aktif plantar fleksi, secara langsung mengaktifkan otot-otot pada ekstrimitas bawah dan meningkatkan sirkulasi pada daerah kaki dengan terjadinya vasodilatasi pembuluh darah di kaki (Sato, 2003; Colberg, Sheri R.Ronald J. Sigal, Bo Fernhall, Judith G. Regensteiner, Bryan J. Blissmer, Richard R. Rubin, Lisa Chasan-Taber, Ann L. Albright, 2010).

Kualitas hidup merupakan sebagai persepsi individu dari posisi mereka dalam kehidupan dalam konteks budaya dan sistem nilai dimana mereka tinggal dan dalam hubungannya dengan tujuan mereka, harapan, standar dan kekhawatiran (WHO, 1996). Konsep ini meliputi beberapa dimensi yang luas yaitu: kesehatan fisik, kesehatan psikologis, hubungan social dan lingkungan. Aspek mengenai kualitas hidup (WHO, 1996), diantaranya sebagai berikut:

1. Kesehatan fisik, diantaranya aktivitas sehari-hari, ketergantungan pada zat obat dan alat bantu medis, energi dan kelelahan, mobilitas, rasa sakit dan ketidaknyamanan, tidur dan istirahat, kapasitas kerja. 
2. Kesejahteraan psikologi, diantaranya image tubuh dan penampilan, perasaan negative, perasaan positif, harga diri, spiritualitas/ agama/ keyakinan pribadi, berpikir, belajar, memori dan konsentrasi.

3. Hubungan sosial, diantaranya hubungan pribadi, dukungan sosial, aktivitas seksual.

4. Hubungan dengan lingkungan, diantaranya sumber keuangan, kebebasan, keamanan fisik dan keamanan Kesehatan dan perawatan sosial : aksesibilitas dan kualitas, lingkungan rumah. Peluang untuk memperoleh informasi dan keterampilan baru, partisipasi dalam dan peluang untuk kegiatan rekreasi / olahraga, lingkungan fisik (polusi / suara / lalu lintas / iklim), mengangkut.

Latihan berjalan yang dilakukan memiliki standar-standar yang harus dipatuhi (Aprina, Eka, 2015), yaitu: 1) Tempat. Tempat latihan dilaksanakan di luar ruangan (out door). Kondisi ini memberikan efek positif bagi responden dimana responden memiliki pandangan yang luas terhadap lingkungan tempat latihan dan dapat menikmati keindahan alam. Selain alasan tersebut latihan berjalan di luar ruangan lebih hemat secara financial karena tidak memerlukan penggunaan alat-alat khusus untuk latihan berjalan; 2) Keamanan. Tempat latihan di luar ruangan dipastikan bukan merupakan tempat lalulintas kendaraan roda dua maupun roda empat sehingga responden akan terhindar dari kecelakaan lalu lintas; 3) Waktu. Waktu latihan dilaksanakan pada pagi hari pada pukul 06:00 - 07:00 WIB. Waktu ini dipilih karena udara pagi hari masih segar, terbebas polusi dan suhu yang tidak terlalu panas. Kondisi ini menghindari terjadinya hipertermia yang akan memicu terjadinya kehilangan banyak cairan dari tubuh responden dan menghindari responden cepat mengalami kelelahan berlebih; 4) Lama latihan. Latihan berjalan pada penelitian ini dilaksanakan dalam waktu 60 menit sekali latihan dan diulang 3 kali dalam seminggu. Setiap latihan selama 60 menit terdiri dari 5 menit pertama sebagai waktu untuk peregangan, 50 menit kedua untuk latihan inti berjalan dan 5 menit terakhir untuk pendinginan atau istirahat; 5) Target latihan. Latihan berjalan harus mencapai target denyut nadi yang disesuaikan dengan umur. Target denyut nadi adalah 60\%-70\% dari maksimum Heart Rate (MHR). MHR = 220 - umur; 6) Berkelompok. Latihan berjalan dilaksanakan secara bersama-sama tidak sendiri-sendiri. Latihan berjalan secara bersama-sama meningkatkan silaturahim. Antar responden bisa bertukar pengalaman dan informasi terkait dengan masalah-masalah yang dialami terkait dengan penyakit yang dialami dan solusinya. Kondisi ini membuat responden tidak merasa sendiri dan menjadi penyemangat untuk tetap melaksanakan latihan berjalan dan 7) Prosedur latihan. Latihan berjalan harus dilakukan sesuai dengan tahapan-tahapan mulai dari persiapan, pemanasan, latihan inti (kecepatan sedang) dan pendinginan.

Jalan sehat yang dilakukan sesuai standar memberikan pengaruh positif. Jalan sehat akan mengakibatkan terjadinya peningkatan aliran darah keseluruh tubuh pada umumnya dan akan memperbaiki aliran darah pada daerah kaki khususnya. Seseorang yang melakukan latihan berjalan terjadi gerakan berulang-ulang secara aktif plantar fleksi, secara langsung mengaktifkan otot-otot pada ekstrimitas bawah dan meningkatkan sirkulasi pada daerah kaki dengan terjadinya vasodilatasi pembuluh darah di kaki (Colberg, Sheri R.Ronald J. Sigal, Bo Fernhall, Judith G. Regensteiner, Bryan J. Blissmer, Richard R. Rubin, Lisa Chasan-Taber, Ann L. Albright, 2010)(Sato, 2003). Selain itu, jalan sehat menurunkan kadar gula yang berikatan dengan darah (HbA1c) yang berdampak baik terhadap kualitas pembuluh darah di kaki khususnya (Aprina, Eka, 2015). Proses fisiologi ini meningkatkan kesehatan fisik penderita DM tipe 2.

Kondisi kaki yang sehat tanpa ada komplikasi kronik akibat DM memberikan kemampuan pada responden dapat melakukan aktivitas lebih mandiri baik di rumah maupun di luar rumah. Jalan sehat yang dilakukan pada penelitian ini dilakukan secara bersama-sama dengan penderita diabetes yang lain. Hal ini memfasilitasi para penderita diabetes mellitus untuk saling bersosialisasi dengan orang lain memberikan rasa kebahagiaan secara psikologi karena dapat bertukar informasi antara penderita terkait dengan kesehatan pribadinya maupun hal-hal lain dalam kehidupannya. Melihat pengaruh positif yang dihasilkan dari aktivitas jalan sehat dimana meningkatkan kesehatan fisik tubuhnya dan memungkinkan 
pasien DM tipe 2 lebih mandiri dalam melakukan aktivitas di dalam maupun di luar rumah dan bisa bersosialisasi dengan orang lain, hal ini meningkatkan kualitas hidup penderita diabetes mellitus tipe 2 .

\section{Pengaruh sosial ekonomi (faktor perancu) terhadap kualitas hidup}

Pada penelitian ini terdapat hubungan yang signifikan antara sosial ekonomi (tingkat pendapatan) dengan kualitas hidup penderita DM tipe 2. Tingkat pendapatan yang rendah dapat menjadi prediktor rendahnya kualitas hidup pasien DM tipe 2. Sosial ekonomi dalam penelitian ini berkaitan dengan pendapatan keuangan yang diperoleh oleh responden dalam setiap bulannya (Yusra, 2011). Pendapatan yang rendah dapat mempengaruhi pemenuhan kebutuhan sehari-hari yang juga akan berdampak langsung terhadap pemenuhan kesehatannya, apalagi penyakit DM merupakan suatu penyakit dimana terjadi gangguan metabolisme yang ditunjukkan dengan tingginya kadar gula dalam darah yang bersifat kronik (Mahdavi et al., 2013) (Kennedy et al., 2013).

\section{Simpulan dan saran}

Simpulan hasil penelitinan menunjukkan jalan sehat meingkatkan kualitas kualitas hidup pada penderita DM tipe 2. Implikasi penelitian khususnya masyarakat, pentingnya upaya Perawat dan tenaga kesehatan terkait untuk melakukan pengawasan, selalu memotivasi pasien DM tipe 2 melakukan jalan sehat dengan benar untuk meningkatkan kualitas hidup penderita DM tipe 2 dan mencegah efek samping dari latihan yang tidak diharapkan.

\section{Referensi}

Aboyans, V., Criqui, M.H., Abraham, P., Allison, M.A., Creager, M.A., Diehm, C., \& Treat, J.D. (2012). Measurement and interpretation of the Ankle-Brachial Index: A scientific statement from the American Heart Association. Circulation, 126(24), 2890-2909. doi: 10.1161/CIR.0b013e318276fbcb

Aprina., \& Eka, I. (2015). Pengaruh jalan sehat terhadap nilai HbAlc pada penderita DM tipe 2 di Puskesmas Wilayah Kotabumi Lampung Utara.

Bosic, Z.D., \& Medic-Stajanoska M.K.Z. (2012). The quality of life in patients with diabetes mellitus type 2.

Brown., G.C., Brown, M.M., Sharma, S., Brown, H., \& Gozum, M. (2000). Quality of life associated with diabetes mellitus in an adult population, 14, 18-24.

Colberg., Sheri, R.R.J., Sigal, B.F., Judith, G.R., Bryan, J.B., Richard R.R., Lisa C.T., Ann L., \& Albright, B.B. (2010). Exercise and Type 2 Diabetes, 13(12). https://doi.org/10.2337/dc10-9990

Crawford, F., Welch, K., Andras, A., Fm, C., Crawford, F., Welch, K., \& Chappell, F. M. (2016). Ankle brachial index for the diagnosis of lower limb peripheral arterial disease ( Review ) Ankle brachial index for the diagnosis of lower limb peripheral arterial disease, (9). https://doi.org/10.1002/14651858.

Gershater, M.A., Löndahl, M., Nyberg, P., Larsson, J., Thörne, J., Eneroth, M., \& Apelqvist, J. (2009). Complexity of factors related to outcome of neuropathic and neuroischaemic/ischaemic diabetic foot ulcers: A cohort study. Diabetologia, 52(3), 398-407. doi: 10.1007/s00125-008-1226-2

Gulve, E.A. (2008). Exercise and Glycemic Control in Diabetes: Benefits, Challanges, and Adjustments to Pharmacotherapy. Physical Therapy, 88(11).

Kennedy, A., Nirantharakumar, K., Chimen, M., Pang, T.T., Hemming, K., Andrews, R.C., \& Narendran, P. (2013). Does Exercise Improve Glycaemic Control in Type 1 Diabetes? A Systematic Review and MetaAnalysis, 8(3). doi: 10.1371/journal.pone.0058861

Mahdavi, A.R., Etemad, K., Haider, M., \& Alavinia, S. M. (2013). The effect of seeing a family physician on the level of glycosylated hemoglobin (HbA1c) in type 2 Diabetes Mellitus patients, 12(1), 1. https://doi.org/10.1186/2251-6581-12-2

Salim, O.C., Sudharma, N.I., Kusumaratna, R.K., \& Hidayat, A. (2007). Validitas dan reliabilitas World Health Organization Quality of Life -BREF untuk mengukur kualitas hidup lanjut usia, 26(1), 27-38.

Sastroasmoro, S.I. (2010). Dasar-dasar metodologi penelitian klinis. Jakarta: Sagung Seto. 
Sato, Y. (2003). Physical Exercise for Diabetes Mellitus: The effective programs for treatment. JMAJ, 46(467), 314-320.

Spasi, A., Veli, R., Cati, A., Stefanovi, N., \& Cvetkovi, T. (2014). Quality of Life in Type 2 Diabetic Patients, 31(3), 193-200. https://doi.org/10.2478/afmnai-2014-0024

Teixeira, C.F.I., Aparecida, G.P.D., Maurício, B.C.A., Polcaro, G.J., Morais, M.L., \& Cunha, B.I. (2007). Correlation between ankle-brachial index before and after shuttle walk test. Correspondence J Vasc Bras, $6(4), 332-8$.

Umpierre, D., Kramer, C.K., Leita, C.B., Gross, J.L., Ribeiro, J.P., \& Schaan, B.D. (2011). Clinician 's corner physical activity advice only or structured with hba 1c levels in type 2 diabetes.

Waspadji, S. (2009). Penatalaksanaan diabetes melitus terpadu sebagai panduan penatalaksanaan diabates melitus bagi dokter maupun edukator. (Cetakan ke). Jakarta: Balai Penerbit FKUI.

WHO. (1996). Introduction, administration, scoring and generic version of the assessment field trial version December 1996 Programme on Mental Health World Health Organization, (December 1996).

WHO. (2004). The World Health Organization Quality Of Life (WHOQOL) -BREF.

WHO. (2010). Global recommendations on physical activity for health.

Yusra, A. (2011). Hubungan antara dukungan keluarga dengan kualitas hidup pasien DM tipe 2 di Poliklinik Penyakit Dalam RSUP Fatmawati Jakarta. Unversitas Indonesai. 